\title{
HUBUNGAN FUNGSI MANAJEMEN KEPALA RUANGAN DENGAN PELAKSANAAN DOKUMENTASI ASUHAN KEPERAWATAN DI RSUD MENGGALA KABUPATEN TULANG BAWANG
}

\author{
Melia Novita ${ }^{1}$, M. Arifki Zainaro ${ }^{2^{*}}$ \\ ${ }^{1}$ Perawat Rumah Sakit Umum Daerah Menggala Kab. \\ MenggalaEmail: melianovita1@gmail.com \\ ${ }^{2}$ Dosen Akademi Keperawatan Malahayati Bandar Lampung \\ Email: m.arifkiz@yahoo.com
}

\section{ABSTRACT: THE CORRELATION BETWEEN MANGEMENT FUNCTION OF WARD HEAD AND DOCUMENTATION OF NURSING CARE AT MENGGALA HOSPITAL OF TULANG BAWANG REGENCY}

Introduction: The head of a ward should conduct coaching and give briefing to the practitioner nurses as well as manage a competence development in nursing documentation, initiation and skill in order to do their duty comprehensibly. In this case, a leader must be able to inform, explain, collaborate and monitor the behavior of the nurses to achieve an ideal situation. The nurse leader should be able to motivate the nurses in charge to perform the best caring which is based on the agreed goal. According to the pre-survey in 2019at Menggala Hospital of Tulang Bawang Regency which is the only type B hospital at the regency, there were 20 patient lists in which 8 patients had incomplete documentation, 2 patients had no physical examination record, 3 patients' interventions were not recorded completely and 7 patients had incomplete nursing care evaluation.

Objective: this study was to identify the correlation between management function of ward head and documentation of nursing care at Menggala Hospital of Tulang Bawang Hospital of Tulang Bawang Regency.

Method: this research used quantitative model. The design of this research is analytic where the research tries to investigate how and why a health phenomenon happened. The approach of the study was cross sectional. The population of this study was the whole nurses in charge at Menggala Hospital of Tulang Bawang Regency in 2018 amounting to 164 people. The minimum samples used in this study were 116 respondents. The sampling technique in this research was proportional random sampling.

Result: the statistical calculation found that $p$ value 0.00 or $p$ value $<0.05$ which indicated there was a correlation between management function of ward head and documentation of nursing care at Menggala Hospital of Tulang Bawang Hospital of Tulang Bawang Regency in 2019. The hospital management should distribute the task to the nurses in line with the functions of each health practitioners in order to make them work based on their functions.

Keywords : Nursing Management, Nursing Documentation 


\section{INTISARI: HUBUNGAN FUNGSI MANAJEMEN KEPALA RUANGAN DENGAN PELAKSANAAN DOKUMENTASI ASUHAN KEPERAWATAN DI RSUD MENGGALA KABUPATEN TULANG BAWANG}

Pendahuluan : Kepala ruang sebagai pemimpin perlu melakukan pembinaan atau pengarahan kepada perawat pelaksana dan pengembangan kemampuan untuk melakukan dokumentasi keperawatan, inisiatif dan keterampilan agar dapat melaksanakan tugasnya dengan baik, dalam hal ini pemimpin harus mampu memberitahu, menjelaskan, bekerja sama dan memonitor perilaku perawat sesuai dengan situasi yang ada untuk dapat meningkatkan motivasi kerja perawat sehingga dapat melaksanakan tugasnya dengan baik dan sesuai dengan tujuan yang telah disepakati. Berdasarkan hasil prasurvey Di RSUD Menggala Kabupaten Tulang Bawang Tahun 2019 dan merupakan satu satunya RS dengan tipe B yaitu diketahui 20 list pasien, dimana terdapat 8 list pasien dengan pengkajian tidak lengkap, 2 list pasien tidak terdapat hasil pemeriksaan fisik, 3 list pasien tidak tercatat intervensi dengan lengkap, dan 7 list pasien tidak terdapat hasil evaluasi asuhan keperawatan yang lengkap.

Tujuan : Untuk mengetahui hubungan fungsi manajemen kepala ruangan dengan pelaksanaan dokumentasi asuhan keperawatan Di RSUD Menggala Kabupaten Tulang Bawang.

Metode : Jenis penelitian yang digunakan dalam penelitian ini adalah kuantitatif. Rancangan dalam penelitian ini menggunakan analitik yang artinya penelitian yang menggali bagaimana dan mengapa fenomena kesehatan itu terjadi, dengan menggunakan pendekatan cross sectional. Populasi dalam penelitian ini adalah seluruh perawat yang ada Di RSUD Menggala Kabupaten Tulang Bawang Tahun 2018 yang berjumlah 164 perawat, Sehingga sampel minimum yang didapatkan berjumlah 116 responden. Dalam penelitian ini teknik sampling yang digunakan adalah proportional random sampling

Hasil : Berdasarkan hasil uji statistik, didapatkan p-value 0,000 atau p-value < 0,05 yang artinya terdapat hubungan fungsi manajemen kepala ruangan dengan pelaksanaan dokumentasi asuhan keperawatan Di RSUD Menggala Kabupaten Tulang Bawang tahun 2019. Diharapkan kepada pihak RSUD agar memberikan tugas sesuai dengan tugas fungsional tenaga kesehatan masing-masing sehingga tidak berlebihan dalam melakukan peran dan fungsi masing-masing tenaga kerja

Kata Kunci : Fungsi Manajemen, Dokumentasi Asuhan Keperawatan

\section{PENDAHULUAN}

Upaya peningkatan derajat kesehatan secara optimal menuntut profesi

keperawatan mengembangkan mutu pelayanan yang profesional sesuai dengan tuntutan masyarakat di era globalisasi. Keperawatan menjadi salah satu profesi terdepan bagi tenaga kesehatan dalam upaya menjaga mutu tempat pelayanan kesehatan baik di masyarakat baik negeri maupun swasta (Kemenkes RI, 2016).
Standar asuhan keperawatan merupakan salah satu strategi mewujudkan bentuk pertanggung jawaban tenaga keperawatan profesional. Dalam perkembangan era globalisasi ini, rumah sakit mengalami perkembangan kuantitas yang cukup pesat. Hal ini dapat dilihat dari semakin banyaknya badan atau institusi yang berusaha mendirikan rumah sakit, baik yang dibiayai dari dalam negeri maupun dari luar negeri. Namun peningkatan 
kuantitas rumah sakit belum diikuti oleh peningkatan mutu pelayanan keperawatan di rumah sakit sehingga sering timbul kontradiksi, dimana rumah sakit banyak mendapat sorotan dan keluhan dari masyarakat sebagai ungkapan rasa tidak puas akibat kurangnya tingkat pelayanan yang diberikan (Arsad, 2018).

Meningkatkan pengetahuan, ketrampilan, sikap dan motivasi bagi tenaga keperawatan, khususnya dalam bentuk seminar atau penataran telah dilakukan, namun hasil yang dicapai belum dapat memuaskan. Hal ini dapat diketahui dari keluhan - keluhan yang disampaikan oleh pasien dan keluarganya maupun masyarakat umum. Rumah Sakit Umum Daerah Tugurejo Semarang merupakan Rumah Sakit Umum Daerah (RSUD) milik Propinsi Jawa Tengah yang memberikan kontribusi penting dalam pelayanan kesehatan di masyarakat (Arsad, 2018).

Tuntutan masyarakat dalam suasana keterbukaan, keluhan keluhaan pasien atas pelayanan rumah sakit semakin mudah disampaikan melalui berbagai media komunikasi, sehingga banyak cara untuk mengkritisi pelayanan rumah sakit, baik pelyanan pasien rawat jalan maupun rawat inap. Dengan maraknya lembaga - lembaga bantuan hukum tidak menolak kemungkinan adanya gugatan terhadap pelayanan rumah sakit maupun terhadap petugas rumah sakit, baik dokter, perawat atas tindakan yang dilakukan dalam rangka pelayanan pasien sehingga muncul adanya gugatan malpraktek (Nursalam, 2016).

Menghadapi kondisi yang demikian itu perawat rumah sakit perlu memahami dan menyadari bahwa apa yang dilakukan pelayanan terhadap pasien harus dilakukan secara profesional disertai rasa tanggung jawab dan tanggung gugat.
Undang - undang No. 23 tahun 1992 merupakan wujud rambu - rambu atas hak dan kewajiban tenaga kesehatan termasuk para perawat dalam menjalankan tugas - tugas pelayanan (Kemenkes. RI, 2016).

Dokumentasi keperawatan dalam bentuk dokumen asuhan keperawatan merupakan salah satu alat pembuktian atas perbuatan perawat selama menjalankan tugas pelayanan keperawatan. Dokumentasi asuhan keperawatan menjadikan hal yang penting sebagai alat bukti tanggung jawab dan tanggung gugat dari perawat dalam menjalankan tugasnya (Nursalam, 2016).

Perawat profesional dihadapkan pada suatu tuntutan tanggung jawab yang lebih tinggi dan tanggung gugat setiap tindakan yang dilaksanakan. Artinya intervensi keperawatan yang diberikan kepada klien harus dihindarkan terjadinya kesalahan - kesalahan (negligence) dengan melakukan pendekatan proses kepeerawatan dan pendokumentasian yang akurat dan benar. Berkaitan dengan hal tersebut di atas, RSUD Tugurejo senantiasa berupaya untuk memenuhi kebutuhan terlaksananya proses keperawatan dan dokumen asuhan keperawatan yang baik, sebagaimana ditentukan dalam Akreditasi Rumah Sakit, yaitu dengan menyediakan formulir dokumen asuhan keperawatan, membuat prosedur tetap suatu tindakan keperawatan dan penggunaan alat di rumah sakit, serta sarana - sarana lain yang diperlukan. Walaupun dokumen asuhan keperawatan sangat diperlukan untuk kepentingan pasien maupun perawat akan tetapi pada kenyataannya perlengkapan pengisian dokumen masih kurang perhatian sehingga masih banyak dokumen asuhan keperawatan yang 
isinya belum lengkap (Nursalam, 2016).

Kepala ruangan merupakan tenaga perawat yang diberi tugas memimpin satu ruang rawat, dan bertanggung jawab terhadap pemberian asuhan keperawatan, yang berperan sebagai first line manager di sebuah rumah sakit, yang diharapkan mampu melaksanakan fungsi manajemen keperawatan (Maharani, 2017).

Peran dan fungsi kepala ruangan diruang rawat dalam fungsi manajemen keperawatan antara lain perencanaan, pengorganisasian, pengaturan ketenagaan, pengarahan, pengawasan dan pengendalian mutu yang merupakan satu siklus yang saling berkaitan satu sama lain. Kepala ruangan sebagai manajer operasional, yang memimpin secara langsung, dalam mengelola seluruh sumber daya di unit perawatan untuk menghasilkan pelayanan yang bermutu, dan dituntut untuk menjadi motor penggerak, bagi sumber-sumber dan alat-alat dalam suatu organisasi melalui pengambilan keputusan, penentuan kebijakan dan menggerakkan orang lain untuk mencapai tujuan organisasi (Arsad, 2018).

Pemberian asuhan yang aman merupakan asuhan keperawatan yang efektif, tepat waktu, dan memenuhi kebutuhan pasien. Keselamatan pasien merupakan system pemberian asuhan yang aman, melalui penurunan tindakan untuk mencegah terjadinya cedera akibat kesalahan melakukan tindakan yang tidak aman kepada pasien, dan memberikan tindakan terbaik untuk mendapatkan derajat kesehatan pasien yang optimal, sehingga dapat menurunkan biaya perawatan dan mengurangi lama hari rawat pasien (McEachen, 2018).
Kepala ruang sebagai pemimpin perlu melakukan pembinaan atau pengarahan kepada perawat pelaksana dan pengembangan kemampuan untuk melakukan dokumentasi keperawatan, inisiatif dan keterampilan agar dapat melaksanakan tugasnya dengan baik, dalam hal ini pemimpin harus mampu memberitahu, menjelaskan, bekerja sama dan memonitor perilaku perawat sesuai dengan situasi yang ada untuk dapat meningkatkan motivasi kerja perawat sehingga dapat melaksanakan tugasnya dengan baik dan sesuai dengan tujuan yang telah disepakati (Arsad, 2018).

Menurut penelitian Naomi dkk (2015) tentang Hubungan Fungsi Manajemen Kepala Ruangan Terhadap Pelaksanaan Pendokumentasian Asuhan Keperawatan Dirumah Sakit Umum Kabupaten Pangkep, menyebutkan bahwa hasil penelitian menunjukan pelaksanaan pendokumentasian asuhan keperawatan baik dan berdasarkan analisis uji Chi-Square diketahui ada hubungan antara fungsi manajemen perencanaan terhadap pelaksanaan pendokumentasian asuhan keperawatan, ada hubungan antara fungsi manajemen pengorganiasian terhadap pelaksanaan pendokumentasian asuhan keperawatan, ada hubungan antara fungsi manajemen ketenagaan terhadap pelaksanaan pendokumentasian asuhan keperawatan, ada hubungan antara fungsi manajemen pengarahan terhadap pelaksanaan pendokumentasian asuhan keperawatan dan ada hubungan antara fungsi manajemen pengendalian terhadap pelaksanaan pendokumentasian asuhan keperawatan ( $p$-value: 0,001). 
Berdasarkan hasil prasurvey Di RSUD Menggala Kabupaten Tulang Bawang Tahun 2019 dan merupakan satu satunya RS dengan tipe $B$ yaitu diketahui 20 list pasien, dimana terdapat 8 list pasien dengan pengkajian tidak lengkap, 2 list pasien tidak terdapat hasil pemeriksaan fisik, 3 list pasien tidak tercatat intervensi dengan lengkap, dan 7 list pasien tidak terdapat hasil evaluasi asuhan keperawatan yang lengkap. Setelah dilakukan wawancara kepada perawat, diketahui bahwa penyebabnya adalah dikarenakan sibuk dengan banyaknya jumlah pasien, sehingga perawat kurang fokus dalam menuliskan asuhan keperawatan, sehingga tidak lengkap dalam menuliskan dokumentasi asuhan keperawatan. Setelah dilakukan wawancara kepada kepala ruangan, kepala ruangan mengatakan bahwa telah menginformasikan agar dapat melengkapi asuhan keperawatan pada list pasien, namun karena kesibukan perawat dengan jumlah pasien yang banyak, maka akibatnya list pasien kurang lengkap.

Berdasarkan latar belakang tersebut, penulis tertarik untuk mengetahui "Hubungan Fungsi Manajemen Kepala Ruangan Dengan Pelaksanaan Dokumentasi Asuhan Keperawatan Di RSUD Menggala Kabupaten Tulang Bawang Tahun 2019".

\section{Rumusan Masalah}

Berdasarkan masalah dan latar belakang di atas, maka rumusan masalah penelitian di atas adalah "Apakah Ada Hubungan Fungsi Manajemen Kepala Ruangan Dengan Pelaksanaan Dokumentasi Asuhan Keperawatan Di RSUD Menggala Kabupaten Tulang Bawang Tahun 2019"?.

\section{Hipotesis}

Hipotesis adalah jawaban sementara dari suatu penelitian. Hasil suatu penelitian pada hakikatnya adalah suatu jawaban atas pertanyaan penelitian yang telah dirumuskan. Jadi hipotesis didalam penelitian berarti jawaban sementara penelitian, patokan duga atau detail sementara, yang kebenarannya akan dibuktikan dalam penelitian tersebut (Setiadi, 2007).

Hipotesis dalam penelitian adalah :

$\mathrm{Ha}$ Ada hubungan fungsi manajemen kepala ruangan dengan pelaksanaan dokumentasi asuhan keperawatan Di RSUD Menggala Kabupaten Tulang Bawang Tahun 2019.

\section{METODE PENELITIAN \\ Jenis Penelitian}

Jenis penelitian yang digunakan dalam penelitian ini adalah kuantitatif yaitu penelitian yang berlandaskan filsafat positivisme, digunakan untuk meneliti pada populasi dan sampel tertentu, pengumpulan data menggunakan instrument penelitian, analisis data bersifat kuantitatif statistik dengan tujuan untuk menguji hipotesis (Sulistyaningsih, 2016).

\section{Populasi}

Populasi adalah keseluruhan objek peneliti yang akan diteliti (Setiadi, 2007). Populasi dalam penelitian ini adalah seluruh perawat rawat inap yang ada Di RSUD Menggala Kabupaten Tulang Bawang yang berjumlah 75 perawat.

\section{Sampel}

Sampel penelitian adalah sebagian dari keseluruhan obyek yang diteliti dan dianggap mewakili seluruh populasi (Setiadi, 2007). Sampel dalam penelitian ini adalah seluruh perawat rawat inap yang ada $\mathrm{Di}$ RSUD Menggala Kabupaten Tulang Bawang yang berjumlah 75 perawat 


\section{Rancangan Penelitian}

Rancangan dalam penelitian ini menggunakan analitik yang artinya penelitian yang menggali bagaimana dan mengapa fenomena kesehatan itu terjadi, dengan menggunakan pendekatan cross sectional yaitu mengumpulkan faktor risiko/penyebab (variabel bebas) dan efek/akibat (variabel terikat) secara bersamaan (Sulistyaningsih, 2016).

\section{Variabel Penelitian}

Variabel penelitian adalah segala sesuatu yang berbentuk apa saja yang diterapkan oleh peneliti untuk dipelajari sehingga diperoleh informasi tentang hal tersebut, kemudian di tarik kesimpulannya (Aprina, 2015).

Variabel Independen

Menurut Notoatmodjo (2010), variabel ini sering disebut sebagai variabel stimulus atau variabel bebas. Variabel bebas merupakan variabel yang memengaruhi atau yang menjadi sebab perubahannya atau timbul nya variabel dependen (terikat) dalam penelitian ini yang menjadi variabel independen adalah fungsi manajemen kepala ruangan.

Variabel Dependen

Variabel ini sering disebut sebagai variabel atau variabel terikat. Variabel terikat merupakan variabel yang dipengaruhi atau yang menjadi akibat. Variabel dependen adalah pelaksanaan asuhan dokumentasi keperawatan.

\section{Definisi Operasional}

Definisi Operasional adalah seperangkat instruksi yang disusun secara lengkap untuk menetapkan variabel apa yang akan diukur dan bagaimana cara mengukur variabel (Aprina, 2015).

\section{Alat Ukur Penelitian}

Dalam melakukan pengumpulan data, alat ukur yang peneliti gunakan adalah lembar kuesioner yang berisi tentang peran kepala ruangan dan pelaksanaan dokumentasi asuhan keperawatan. Untuk variabel fungsi manajemen kepala ruangan, peneliti menggunakan kuesioner yang terdiri dari 20 pernyataan dengan option jawaban selalu (4), sering (3), kadang-kadang (2), dan tidak pernah (1), sehingga skor tertinggi adalah 80 , sedangkan untuk variabel pelaksanaan dokumentasi asuhan keperawatan, peneliti menggunakan lembar kuesioner yang terdiri dari 23 pernyataan dengan option jawaban selalu (4), sering (3), kadang-kadang (2), dan tidak pernah (1), sehingga skor tertinggi adalah 92 .

\section{Uji Validitas}

Menunjukan sejauh mana suatu alat (instrument) mengukur apa yang seharusnya diukur (Notoatmodjo, 2010). Dikatakan valid apabila $r$ hitung lebih besar $r$ tabel maka Ho diterima, sedangkan apabila $r$ hitung lebih kecil $r$ tabel maka Ho gagal ditolak (Aprina, 2015). Peneliti melakukan uji validitas Di RSAM dr.H.Abdoel Moeloek Bandar Lampung karena sesuai dengan tipe RS yang peneliti lakukan yaitu tipe $B$ terhadap 20 responden. Berdasarkan hasil uji valid yang peneliti lakukan diketahui untuk variabel fungsi manajemen kepala ruangan terdiri dari 20 soal, dimana terdapat 3 soal yang tidak valid, dan diketahui untuk variabel pelaksanakan dokumentasi asuhan keperawatan terdiri dari 23 soal, dimana yang tidak valid hanya 3 soal. Berdasarkan analisis data uji valid, diketahui nilai $r$ hitung untuk variabel fungsi manajemen kepala ruangan dan pelaksanaan dokumentasi keperawatan adalah 0,682 - 0,947, dan $r$ table untuk 20 responden adalah 0,444 , sehingga $r$ hitung $>r$ table atau 0,682 - 0,947 > 0,444 , sehingga instrument yang peneliti gunakan sudah teruji validitasnya. 
Uji Reliabilitas

Seberapa besar variasi tidak sistemik dari penjelasan kuantitatif dari karateristik individu jika individu yang sama diukur berkali-kali (Notoatmodjo, 2010). Ukuran yang menunjukkan stabilitas dan kosistensi suatu instrument yang mengukur suatu konsep dan berguna untuk mengukur kebaikan (goodness) dari pengukuran suatu pengukur. Dikatakan reliable apabila cronbach alpha> $r$ hitung maka Ho ditolak (Aprina, 2015). Berdasarkan uji reliabilitas, diketahui nilai $r$ alpha untuk variabel fungsi manajemen kepala ruangan dan pelaksanaan asuhan dokumentasi keperawatan adalah 0,971, sehingga $r$ alpha $>r$ table atau 0,971 >0,444, sehingga instrument yang peneliti gunakan sudah teruji nilai reliabilitasnya.

\section{Tehknik Pengumpulan Data}

Teknik pengambilan data dilakukan berdasarkan data primer, yaitu data yang diambil dari hasil pengisian kuesioner yang diberikan kepada perawat, setelah data didapatkan maka akan dilakukan analisis data dengan bantuan program komputer. Pengolahan Data

Setelah data terkumpul, maka langkah yang dilakukan berikutnya adalah pengolahan data. Proses pengolahan data, Meliputi : (Notoatmojo, 2010)

\section{Editing}

Kegiatan ini untuk melakukan pengecekan lembar hasil penelitian apakah sudah lengkap, jelas dan relevan.

\section{Coding}

Kegiatan merubah data berbentuk huruf menjadi data berbentuk angka atau bilangan untuk mempermudah entry data. Dalam melakukan data, untuk variabel fungsi manajemen kepala ruangan, jika baik maka akan diberi kode 0 , dan jika kurang baik maka akan diberi kode 1 , sedangkan untuk variable pelaksanaan asuhan dokumentasi keperawatan, jika baik maka akan diberi kode 0 , dan jika kurang baik maka akan diberi kode 1 .

\section{Processing}

Proses memasukan data dari lembar kuesioner ke program komputer agar data dianalisis. Dalam melakukan pengolahan data, peneliti melakuka proses perhitungan analisis univariat dan bivariate dengan ketentuan dan rumus yang telah ditetapkan.

\section{Cleaning}

Kegiatan pengecekan kembali data yang di entry kedalam computer agar tidak terdapat kesalahan. Dalam melakukan pengolah data peneliti melakukan pemeriksaan data, jika terdapat kesalahan atau eror dalam melakukan pengolahan data maka akan muncul keterangan missing yaitu keterangan terdapat kesalahan dalam melakukan pengolahan data.

\section{Analisis Univariat}

Analisi univariat bertujuan untuk menjelaskan atau mendiskriptifkan karateristik setiap variabel penelitian. Bentuk analisis univariat tergantung dari jenis datanya (Notoatmojo, 2010).

\section{Analisis Bivariat}

Analisis bivariat digunakan untuk melihat hubungan fungsi manajemen kepala ruangan dengan pelaksanaan asuhan dokumentasi keperawatan. Dalam penelitian ini peneliti menggunakan uji chi-square, jika terdapat nilai $\mathrm{p}$-value $<0,05$, maka $\mathrm{Ha}$ diterima, begitu juga dengan sebaliknya jika $p$-value $>0,05$, maka Ho diterima. Didalam uji chi-square akan didapatkan nilai OR (Odd Ratio) yaitu nilai peluang terjadinya peristiwa, nilai OR akan muncul apabila tabel analisis bivariat yang disajikan adalah $2 \times 2$. (Notoatmojo, 2010). 


\begin{tabular}{|c|c|c|}
\hline $\begin{array}{l}\text { Hasil Penelit } \\
\text { Karateristik } \\
\text { Usia Respon } \\
\text { Tabel } 1 . \\
\text { Distribusi Fre } \\
\text { Di RSUD Men } \\
\text { Bawang Tahu }\end{array}$ & $\begin{array}{l}\text { an } \\
\text { Responder } \\
\text { en } \\
\text { kuensi Usi } \\
\text { gala Kabu } \\
2019\end{array}$ & $\begin{array}{l}\text { Respond } \\
\text { ten Tula }\end{array}$ \\
\hline $\begin{array}{l}\text { Usia } \\
\text { Respond } \\
\text { en }\end{array}$ & $\begin{array}{l}\text { Frekuen } \\
\text { si }\end{array}$ & $\begin{array}{c}\text { Persenta } \\
\text { se (\%) }\end{array}$ \\
\hline $\begin{array}{l}25-32 \\
\text { Tahun }\end{array}$ & 42 & 56,0 \\
\hline $\begin{array}{l}33-43 \\
\text { Tahun }\end{array}$ & 33 & 44,0 \\
\hline Jumlah & 75 & 100,0 \\
\hline
\end{tabular}

Berdasarkan tabel 1, diketahui bahwa Di RSUD Menggala Kabupaten Tulang Bawang Tahun 2019, sebagian besar usia perawat 25-32 tahun yang berjumlah 42 perawat $(56,0 \%)$

Jenis Kelamin

Tabel 2.

Distribusi Frekuensi Jenis Kelamin Responden Di RSUD Menggala Kabupaten Tulang Bawang Tahun 2019

\begin{tabular}{ccc}
$\begin{array}{c}\text { Jenis } \\
\text { Kelamin }\end{array}$ & $\begin{array}{c}\text { Frekuen } \\
\text { si }\end{array}$ & $\begin{array}{c}\text { Persenta } \\
\text { se (\%) }\end{array}$ \\
\hline Laki-Laki & 35 & 46,7 \\
\cline { 1 - 2 } $\begin{array}{c}\text { Perempu } \\
\text { an }\end{array}$ & 40 & 53,3 \\
\cline { 1 - 1 } Jumlah & 75 & 100,0 \\
\hline
\end{tabular}

Berdasarkan tabel 2, diketahui bahwa Di RSUD Menggala Kabupaten Tulang Bawang Tahun 2019, sebagian besar jenis kelamin perawat adalah perempuan yang berjumlah 40 perawat $(53,3 \%)$.

\section{Masa Kerja}

Tabel 3.

Distribusi Frekuensi Masa Kerja

Responden Di RSUD Menggala Kabupaten Tulang Bawang Tahun 2019.

\begin{tabular}{ccc}
\hline $\begin{array}{c}\text { Masa } \\
\text { Kerja }\end{array}$ & $\begin{array}{c}\text { Frekuens } \\
\mathbf{i}\end{array}$ & $\begin{array}{c}\text { Persentas } \\
\mathbf{e}(\%)\end{array}$ \\
\hline $\begin{array}{c}\text { Tahun } \\
\text { Tahun }\end{array}$ & 56 & 74,6 \\
\cline { 1 - 1 } $\begin{array}{c}7-13 \\
\text { Tahun }\end{array}$ & 19 & 25,4 \\
\cline { 1 - 2 } $\begin{array}{c}\text { Jumla } \\
\text { h }\end{array}$ & 75 & 100,0 \\
\cline { 1 - 2 } & &
\end{tabular}

Berdasarkan tabel 3, diketahui bahwa Di RSUD Menggala Kabupaten Tulang Bawang Tahun 2019, sebagian besar masa kerja perawat 2-6 tahun berjumlah 56 responden (74,6\%).

\section{Pendidikan}

Tabel 4.

Distribusi Frekuensi Pendidikan Responden Di RSUD Menggala Kabupaten Tulang Bawang Tahun 2019

\begin{tabular}{ccc}
\hline Pendidikan & Frekuensi & $\begin{array}{c}\text { Persentase } \\
(\%)\end{array}$ \\
\cline { 3 - 3 } D III & 46 & 61,3 \\
\hline S1 & 19 & 25,3 \\
\hline Profesi & 10 & 13,4 \\
\hline Jumlah & $\mathbf{7 5}$ & 100,0 \\
\hline
\end{tabular}

Berdasarkan tabel 4, diketahui bahwa Di RSUD Menggala Kabupaten Tulang Bawang Tahun 2019, sebagian besar pendidikan perawat adalah DIII berjumlah 46 responden $(61,3 \%)$.

\section{Analisis Univariat}

Fungsi Manajemen Kepala Ruangan

Tabel 5.

Distribusi Frekuensi Fungsi

Manajemen Kepala Ruangan Di RSUD Menggala Kabupaten Tulang Bawang Tahun 2019

\begin{tabular}{ccc}
\hline $\begin{array}{c}\text { Fungsi } \\
\text { Manajem } \\
\text { en Kepala } \\
\text { Ruangan }\end{array}$ & $\begin{array}{c}\text { Frekuen } \\
\text { si }\end{array}$ & $\begin{array}{c}\text { Persenta } \\
\text { se (\%) }\end{array}$ \\
\cline { 1 - 2 }$\frac{\text { Baik }}{\text { Kurang }}$ & 31 & 41,3 \\
\hline $\begin{array}{c}\text { Baik } \\
\text { Jumlah }\end{array}$ & 74 & 58,7 \\
\cline { 1 - 2 } & 75 & 100,0 \\
\hline
\end{tabular}


Berdasarkan tabel 5, diketahui bahwa Di RSUD Menggala Kabupaten Tulang Bawang Tahun 2019, sebagian besar fungsi manajemen kepala ruangan kurang baik berjumlah 44 responden $(58,7 \%)$

\section{Pelaksanaan Asuhan Dokumentasi Keperawatan}

Tabel 6.

Distribusi Frekuensi Pelaksanaan Dokumentasi Asuhan Keperawatan Di RSUD Menggala Kabupaten Tulang Bawang Tahun 2019

\begin{tabular}{|c|c|c|}
\hline $\begin{array}{l}\text { Pelaksana } \\
\text { an } \\
\text { Dokument } \\
\text { asi Asuhan } \\
\text { Keperawa } \\
\text { tan } \\
\end{array}$ & $\begin{array}{c}\text { Frekue } \\
\text { nsi }\end{array}$ & $\begin{array}{c}\text { Persenta } \\
\text { se (\%) }\end{array}$ \\
\hline Baik & 33 & 44,0 \\
\hline $\begin{array}{c}\text { Kurang } \\
\text { Baik }\end{array}$ & $\overline{42}$ & 56,0 \\
\hline Jumlah & 75 & 100,0 \\
\hline
\end{tabular}

Berdasarkan tabel 4.6, diketahui bahwa Di RSUD Menggala Kabupaten Tulang Bawang Tahun 2019, sebagian besar pelaksanaan asuhan dokumentasi keperawatan kurang baik berjumlah 42 responden (56,0\%).

\section{Analisa Bivariat}

Untuk mengetahui hubungan fungsi manajemen kepala ruangan dengan pelaksanaan dokumentasi asuhan keperawatan Di RSUD Menggala Kabupaten Tulang Bawang, maka digunakan analisa bivariat, yaitu:
Hubungan
Fungsi
Manajemen
Kepala
Ruangan Dengan
Pelaksanaan Dokumentasi Asuhan Keperawatan

Tabel 4.7. Analisis hubungan fungsi manajemen kepala ruangan dengan pelaksanaan dokumentasi asuhan keperawatan Di RSUD Menggala Kabupaten Tulang Bawang Tahun 2019
Berdasarkan tabel 7, diketahui bahwa Di RSUD Menggala Kabupaten Tulang Bawang Tahun 2019, terdapat 31 perawat yang mengatakan fungsi manajemen kepala ruangan baik, dimana 25 $(80,6 \%)$ perawat pelaksanaan

dokumentasinya baik, dan $6(19,4 \%)$ perawat pelaksanaan dokumentasinya kurang baik, sedangkan 44 perawat mengatakan fungsi manajemen kepala ruangan kurang baik, dimana $8 \quad(18,2 \%)$ perawat pelaksanaan dokumentasinya baik, dan $36(81,8 \%)$ perawat pelaksanaan dokumentasinya kurang baik. Berdasarkan hasil uji statistik, didapatkan p-value 0,001 atau $\mathrm{p}$-value < 0,05 yang artinya terdapat hubungan fungsi manajemen kepala ruangan dengan pelaksanaan dokumentasi asuhan keperawatan Di RSUD Menggala Kabupaten Tulang Bawang tahun 2019 dengan nilai OR sebesar 18,750 yang artinya fungsi manajemen kepala ruangan yang kurang baik mempunyai peluang 18,750 kali lebih besar mengakibatkan pelaksanaan asuhan dokumentasi keperwatan kurang baik, dibandingkan dengan fungsi manajemen kepala ruangan yang baik.

\section{Pembahasan Univariat}

Fungsi Manajemen Kepala Ruangan

Berdasarkan hasil penelitian, diketahui bahwa Di RSUD Menggala

Kabupaten Tulang Bawang Tahun 2019, sebagian besar fungsi manajemen kepala ruangan kurang baik berjumlah 44 responden (58,7\%).

Hasil penelitian ini sejalan dengan teori Nursalam (2016), manajemen keperawatan merupakan suatu bentuk koordinasi dan integrasi sumber-sumber keperawatan dengan menerapkan proses manajemen untuk mencapai 
tujuan dan obyektifitas asuhan keperawatan dan pelayanan keperawatan dan juga teori menurut Arsad (2018), manajemen keperawatan adalah proses kerja setiap perawat untuk memberikan pengobatan dan kenyamanan terhadap pasien. Tugas manager keperawatan adalah merencanakan, mengatur, mengarahkan dan mengawasi keuangan yang ada, peralatan dan sumber daya manusia untuk memberikan pengobatan yang efektif dan ekonomis kepada pasien. Hasil penelitian ini sejalan dengan penelitian Sitti Raodhah, Nildawati dan Rezky tentang Hubungan Peran Kepala Ruangan Dengan Kinerja Perawat Di Ruang Rawat Inap RSUD Syekh Yusuf Kabupaten Gowa, menyebutkan bahwa Dari analisis univariat diketahui bahwa rata-rata peran kepala ruangan kurang baik mencapai 63,3\% dan kinerja perawat juga kurang baik mencapai $57,4 \%$.

Menurut pendapat peneliti bahwa salah satu penyebab fungsi manajemen kepala ruangan kurang baik adalah berdasarkan hasil penilaian terhadap instrument penelitian diketahui terdapat aspek yang paling rendah ada pada soal no 8 yaitu mengenai kepala ruangan kurang mengenal jenis dan kegunaan barang peralatan serta mengusahakan pengadaannya sesuai kebutuhan pasien agar tercapainya pelayanan optimal, sedangkan aspek yang paling tinggi ada di soal no 10 yaitu mengenai kepala ruangan telah melaksanakan program orientasi kepada pasien dan keluarganya meliputi tentang peraturan rumah sakit, tata tertib ruangan, fasilitas yang ada dan cara penggunaannya.

Berdasarkan hasil analisis diatas, maka menurut peneliti kekurangan kepala ruangan adalah diketahui kepala ruangan kurang memahami serta melaksanakan perencanaan dan evaluasi pada kinerja dalam memantau dan menilai asuhan dokumentasi keperawatan, kepala ruangan kurang dalam memberikan dukungan serta pengarahan kepada perawatnya agar selalu mengingatkan dan melakukan supervisi terhadap hasil kerja perawat dalam menuliskan asuhan dokumentasi keperawatan.

Pelaksanaan Asuhan Dokumentasi Keperawatan

Berdasarkan hasil penelitian diketahui bahwa Di RSUD Menggala Kabupaten Tulang Bawang Tahun 2019, sebagian besar pelaksanaan asuhan dokumentasi keperawatan kurang baik berjumlah 42 responden (56,0\%).

Hasil penelitian ini sejalan dengan teori Nursalam (2016), bahwa dokumentasi keperawatan merupakan salah satu alat pembuktian atas perbuatan perawat selama menjalankan tugas pelayanan keperawatan. Dokumentasi asuhan keperawatan menjadikan hal yang penting sebagai alat bukti tanggung jawab dan tanggung gugat dari perawat dalam menjalankan tugasnya. Walaupun dokumen asuhan keperawatan sangat diperlukan untuk kepentingan pasien maupun perawat akan tetapi pada kenyataannya perlengkapan pengisian dokumen masih kurang perhatian sehingga masih banyak dokumen asuhan keperawatan yang isinya belum lengkap.

Hasil penelitian ini sejalan dengan penelitian Naomi Malaha, Elly. L. Sjattar, dan Irfan Idris tentang Hubungan Fungsi Manajerial Kepala Ruangan Terhadap Pelaksanaan Pendokumentasian Asuhan Keperawatan Dirumah Sakit Umum Kabupaten Pangkep Tahun 2015, menyebutkan bahwa hasil penelitian menunjukan pelaksanaan pendokumentasian asuhan keperawatan baik (64,8\%). Fungsi manajerial kepala ruang yaitu fungsi perencanaan baik $(62,0 \%)$, (2) fungsi 
pengorganisasian $\mathrm{t} i \mathrm{~d}$ a $\mathrm{k}$ baik $(80,3 \%)$, (3) fungsi pengarahan baik $(59,2 \%)$, (4) fungsi pengawasan kurang baik $(80,3 \%)$, fungsi pengendalian baik $\left(57,7^{\circ} \%\right)$.

Menurut pendapat peneliti bahwa salah satu penyebab pelaksanaan asuhan dokumentasi keperawatan kurang baik adalah berdasarkan hasil penilaian terhadap instrument penelitian, diketahui terdapat aspek yang paling rendah ada pada soal no 1 yaitu mengenai banyak perawat tidak mencatat data yang dikaji sesuai dengan pedoman pengkajian, dan aspek yang paling tinggi ada di soal no 2 yaitu tentang perawat telah melakukan data yang dikelompokkan (bio-psiko-sosialspiritual).

Menurut pendapat peneliti bahwa beberapa faktor yang menyebabkan pelaksanaan asuhan dokumentasi keperawatan kurang baik dikarenakan perawat lebih sibuk dengan pekerjaan dalam memberikan tindakan kepada pasien, seperti mengganti balutan, melakukan injection, dan lain-lain hal ini dipicu karena banyaknya pasien yang dilakukan rawat inap, sehingga rata-rata perawat yang ada di ruangan terlalu fokus dengan tindakan di ruangan, sehingga melupakan peran dan tanggung jawab perawat dalam menuliskan asuhan keperawatan, dilain sisi juga tidak adanya monitoring dari kepala ruangan mengenai kelengkapan formulir yang di isi dalam dokumentasi asuhan keperawatan, sehingga mengakibatkan banyak dokumentasi asuhan keperawatan yang tidak terisi, seperti pengkajian tindak lengkap, diagnosis hanya dari dokter saja, dan tidak adanya catatan perkembangan pasien.

\section{Pembahasan Bivariat \\ Hubungan Fungsi Manajemen \\ Kepala Ruangan Dengan \\ Pelaksanaan Dokumentasi Asuhan Keperawatan}

Berdasarkan hasil penelitian, diketahui bahwa Di RSUD Menggala Kabupaten Tulang Bawang Tahun 2019, terdapat 31 perawat yang mengatakan fungsi manajemen kepala ruangan baik, dimana 25 $(80,6 \%)$ perawat pelaksanaan

dokumentasinya baik, dan $6(19,4 \%)$ perawat pelaksanaan dokumentasinya kurang baik, sedangkan 44 perawat mengatakan fungsi manajemen kepala ruangan kurang baik, dimana $8 \quad(18,2 \%)$ perawat pelaksanaan dokumentasinya baik, dan $36(81,8 \%)$ perawat pelaksanaan dokumentasinya kurang baik.

Hasil penelitian ini sejalan dengan teori Arsad (2018), peran dan fungsi kepala ruangan diruang rawat dalam fungsi manajemen keperawatan antara lain perencanaan, pengorganisasian, pengaturan ketenagaan, pengarahan, pengawasan dan pengendalian mutu yang merupakan satu siklus yang saling berkaitan satu sama lain. Kepala ruangan sebagai manajer operasional, yang memimpin secara langsung, dalam mengelola seluruh sumber daya di unit perawatan untuk menghasilkan pelayanan yang bermutu, dan dituntut untuk menjadi motor penggerak, bagi sumber-sumber dan alat-alat dalam suatu organisasi melalui pengambilan keputusan, penentuan kebijakan dan menggerakkan orang lain untuk mencapai tujuan organisasi.

Hasil penelitian ini juga sejalan dengan teori McEachen (2018), pemberian asuhan yang aman merupakan asuhan keperawatan yang efektif, tepat waktu, dan memenuhi kebutuhan pasien. Keselamatan pasien 
merupakan system pemberian asuhan yang aman, melalui penurunan tindakan untuk mencegah terjadinya cedera akibat kesalahan melakukan tindakan yang tidak aman kepada pasien, dan memberikan tindakan terbaik untuk mendapatkan derajat kesehatan pasien yang optimal, sehingga dapat menurunkan biaya perawatan dan mengurangi lama hari rawat pasien.

Hasil penelitian ini sejalan dengan penelitian Sitti Raodhah, Nildawati dan Rezky tentang Hubungan Peran Kepala Ruangan Dengan Kinerja Perawat Di Ruang Rawat Inap RSUD Syekh Yusuf Kabupaten Gowa, menyebutkan bahwa Dari analisis bivariat diperoleh hubungan peran kepala ruangan dengan kinerja perawat di ruang rawat inap RSUD Syekh Yusuf Kabupaten Gowa (variable Perencanaan, $(p=0,014)$, Pengorganis asian, $(p=0,008)$, Pengarahan, $(p=0,02$ 4), Pengawasan / Pengendalian $(p=0,009)$ dari semua peran kepala ruangan dihub-ungkan dengan kinerja perawat dapat diperoleh $(p=0,014))$. Penelitian ini menunjukkan bahwa kinerja perawat di ruang rawat inap RSUD Syekh Yusuf Kabupaten Gowa dipengaruhi oleh peran kepala ruangan.

Berdasarkan analisa dari hasil penelitian diatas, maka diketahui adanya hubungan antara fungsi manajemen kepala ruangan terhadap pelaksanaan asuhan dokumentasi keperawatan, hal ini dibuktikan dengan nilai p-value < 0,05 yaitu 0,001 , dan juga diketahui bahwa terdapat nilai OR sebesar 18,750 yang artinya fungsi manajemen kepala ruangan yang kurang baik mempunyai peluang 18,750 kali lebih besar mengakibatkan pelaksanaan asuhan dokumentasi keperwatan kurang baik, dibandingkan dengan fungsi manajemen kepala ruangan yang baik.

Menurut pendapat peneliti bahwa berdasarkan hasil penelitian diketahui terdapat manajemen kepala ruangan baik, namun terdapat perawat yang melakukan pendokumentasian asuhan keperawatan kurang baik, hal ini dipengaruhi oleh faktor usia dan masa kerja, rata-rata usia responden serta masa kerja responden sudah lama dan kurang produktif dalam melaksanakan tugas serta peran tanggung jawab dalam melaksanakan asuhan dikumentasi keperawatan, sedangkan ada beberapa perawat mengatakan fungsi manajemen kepala ruangan kurang baik, namun terdapat perawat yang melaksanakan asuhan dokumentasi dengan baik, hal ini dikarenakan pendidikan perawat yang sudah mempunyai jenjang tinggi seperti S1 dan profesi, sehingga perawat lebih paham dan menyadari bahwa asuhan dokumentasi keperawatan sangat penting untuk dilakukan agar dapat menilai dan memantau status kesehatan pasien. Berdasarkan hasil penilaian terhadap instrument penelitian, diketahui bahwa ratarata kepala ruangan tidak mengetahui tetang perannya sebagai mengendalikan, mengevaluasi serta merencanakan program kinerja perawat yang ada diruangan khususnya dalam pelaksanaan asuhan dokumentasi keperawatan.

\section{KESIMPULAN DAN SARAN Kesimpulan}

Berdasarkan hasil penelitian diatas, maka kesimpulan dalam penelitian ini adalah sebagai berikut:

Diketahui bahwa Di RSUD Menggala Kabupaten Tulang Bawang Tahun 2019, sebagian besar fungsi manajemen kepala ruangan kurang baik berjumlah 44 responden $(58,7 \%)$ 
Diketahui bahwa Di RSUD Menggala Kabupaten Tulang Bawang Tahun 2019, sebagian besar pelaksanaan asuhan dokumentasi keperawatan kurang baik berjumlah 42 responden $(56,0 \%)$.

Berdasarkan hasil uji statistik, didapatkan $\mathrm{p}$-value 0,000 atau $p$-value $<0,05$ yang artinya terdapat hubungan fungsi manajemen kepala ruangan dengan pelaksanaan dokumentasi asuhan keperawatan Di RSUD Menggala Kabupaten Tulang Bawang tahun 2019.

\section{Saran}

\section{Bagi Responden}

Diharapkan responden mampu meningkatkan, merubah dan memperbaiki fungsi manajemen dalam ruangan dengan cara mengikuti kegiatan pelatihan atau seminar tentang mutu kualitas kerja dan produktivitas kerja, sehingga fungsi manajemen dalam ruangan tercapai dengan maksimal.

Bagi RSUD Menggala Kabupaten Tulang Bawang

a) Diharapkan kepada pihak RSUD Menggala agar dapat membuat regulasi undang-undang tentang pelaksanaan asuhan dokumentasi keperawatan.

b) Meningkatkan reward kepada kepala ruangan dan perawat yang mempunyai prestasi kerja yang baik.

c) Dibuat ruang khusus konsultasi asuhan dokumentasi keperawatan

d) Mengadakan seminar dan pelatihan tentang mutu kualitas kerja dan produktivitas kerja bagi kepala ruangan dan perawat.

Kepala Ruangan

a) Diharapkan kepala ruangan lebih aktif dalam menjalankan fungsi manajemen didalam ruangan seperti harus mengenal jenis dan kegunaan barang peralatan serta mengusahakan pengadaannya sesuai kebutuhan pasien agar tercapainya pelayanan optimal.

b) Diharapkan kepala ruangan mampu mengevaluasi kinerja perawat dalam melakukan pencatatan data yang dikaji sesuai dengan pedoman pengkajian

c) Diharapkan kepala ruangan agar dapat mengikuti pelatihan atau seminar mengenai fungsi manajemen sebagai kepala ruangan.

Bagi Peneliti Selanjutnya Diharapkan untuk peneliti

selanjutnya agar dapat melakukan penelitian lebih lanjut tentang faktor-faktor lain yang mempengaruhi fungsi manajemen kepala ruangan yaitu organisasi kerja, serta sumber stress kerja yaitu deprivational stress dan peran serta tanggung jawab kepala ruangan.

\section{DAFTAR PUSTAKA}

Aprina. (2015). Riset Penelitian. Bandar lampung: Diklat.

Asmadi. (2008). Konsep Dasar Keperawatan. Jakarta: EGC.

Arsad. (2018). Kepemimpinan Dan Manajemen Keperawatan. Jakarta: Bumi Medika.

Kuntoro, Agus. (2010). Buku Ajar Manajemen Keperawatan. Yogyakarta: Nuha Medika.

Kemenkes, RI. 2016. Profil Kesehatan Republik Indonesia. Jakarta: Kementrian Kesehatan.

McEachen, Irene. (2018). Manajemen Keperawatan. Yogyakarta: Publishing.

Maharani, Yupita Dwi. (2017). Buku Pintar Kebidanan \& 
Keperawatan.

Sleman

Yogyakarta: Brilliant Books.

Nursalam. (2016). Manajemen Keperawatan Aplikasi Dalam Praktik Keperawatan Profesional. Jakarta: Salemba Medika.

Notoadmodjo, Soekidjo. (2012). Metode Penelitian Kesehatan. Jakarta: PT. Rineka Cipta.

Naomi Malaha, Elly. L. Sjattar, dan Irfan Idris Tentang Hubungan Fungsi Manajerial Kepala Ruangan Terhadap Pelaksanaan

Pendokumentasian Asuhan Keperawatan Dirumah Sakit Umum Kabupaten Pangkep Tahun 2015.

Priyoto. (2015). Komunikasi Dan Sikap Empati Dalam Keperawatan. Yogyakarta: Graha IImu.

Priharjo, Robert. (2010). Pengantar Etika Keperawatan. Yogyakarta: Penerbit Kanisius.

Profil Rumah Sakit Umum Daerah Menggala.(2018). Profil Kesehatan RSUD Menggala. Tulang Bawang: Lampung.

Setiadi. (2007). Konsep \& Penulisan Riset Keperawatan.

Yogyakarta: Graha IImu.

Sulistyaningsih. (2016). Metodologi

Penelitian Kebidanan

Kuantitatif-Kualitatif.

Yogyakarta: Graha IImu.

Suarli. (2012). Manajemen Keperawatan Dengan Pendekatan Praktis. Jakarta: Penerbit Erlangga.
Sitti Raodhah, Nildawati dan Rezky Tentang Hubungan Peran Kepala Ruangan Dengan Kinerja Perawat Di Ruang Rawat Inap RSUD Syekh Yusuf Kabupaten Gowa.

Universitas Malahayati. 2018. Pedoman Umum Penulisan Karya Tulis Ilmiah \& Skripsi Program Studi Ilmu Keperawatan Fakultas Kedokteran. Lampung.

Widya N Widodo, Herlina Wungow Dan Rivelino $S$ Hamel Tentang Hubungan Peran Ketua Tim Dengan Kinerja Perawat Pelaksana Dalam Pendokumentasian Asuhan Keperawatan Di Irina F RSUP Prof Dr. R. D. Kandou Manado. 